Care: Jurnal Ilmiah Ilmu Kesehatan Vol.8, No.3, 2020, hal 472-482

Tersedia online di https://jurnal.unitri.ac.id/index.php/care

ISSN 2527-8487 (online)

ISSN 2089-4503 (cetak)

\title{
TERDAPAT PERBEDAAN PENGARUH CIRCUIT BODY WEIGHT TRAINING (CBWT) SUBMAKSIMAL TERHADAP PENURUNAN PERSENTASE LEMAK TUBUH, LEMAK SUBKUTAN DAN MENINGKATKAN OTOT SKELETAL
}

\author{
A. Agam Haris Pambudi ${ }^{1)}$, Paulus Liben²), Purwo Sri Rejeki ${ }^{3)}$ \\ 1) Program Magister Ilmu Kesehatan Olahraga, Fakultas Kedokteran Universitas Airlangga \\ 2),3) Departemen Fisiologi, Fakultas Kedokteran Universitas Airlangga \\ E-mail: agamharis33@gmail.com
}

\begin{abstract}
Physical activity with moderate intensity can be implemented with various types of exercise, including multiple movements done in turns which take a bodyweight as a training load known as the circuit body weight training (CBWT). The purpose of this research to prove influence CBWT moderate intensity to the percentage of the body fat, subcutaneous fat and muscles skeletal a person trained and untrained. This is research experimental with the methods pretest-posttest design. 20 people women aged 18 to 23 years was obtained using proportionate stratified random sampling. Consisting of K1 10 people trained and K2 10 people untrained. Done the measurement of the percentage of the body fat, subcutaneous fat and muscles skeletal use weight body composition monitor model HBF-375 Karada scan. The subject is given the treatment CBWT moderate intensity (64-76\% heart rate maximum) for 30 menit, after which the measurement was done again 5 minutes after treatment. The data were analyzed using the SPSS statistical tests with paired t-test and the continued independent t-test. Body fat pre K1 mean $\Delta(0,53 \% \pm 0,28)$, and $K 2$ mean $\Delta(0,92 \% \pm 0,69)$, the value of $p=0,119$ ( $p<0,05)$. Subcutaneous pre $K 1$ mean $\Delta(0,34 \% \pm$ $0,16)$, and $K 2$ mean $\Delta(0,43 \% \pm 0,40)$, the value of $p=0,528(p<0,05)$. Skeletal muscle pre K1 mean $\Delta(0,41 \% \pm 0,23)$, and $K 2$ mean $\Delta(0,33 \% \pm 0,29)$, the value of $p=0,506(p<0,05)$. CBWT moderate intensity can decrease the percentage of body fat, subcutaneous fat and increases muscle skeletal on K1 and K2, but not significant.
\end{abstract}

Keywords : Body composition; CBWT; trained people; untrained people.

\begin{abstract}
ABSTRAK
Aktivitas fisik submaksimal dapat dilaksanakan dengan berbagai tipe latihan salah satunya melakukan berbagai jenis gerakan yang dilakukan secara bergantian dan menjadikan berat badan tubuh sebagai beban latihan atau disebut circuit body weight training (CBWT). Tujuan penelitian ini untuk membuktikan pengaruh CBWT submaksimal terhadap persentase lemak tubuh, lemak subkutan dan otot skeletal orang terlatih dan tidak terlatih. Jenis

Cara mengutip: Pambudi, A.A. Haris., Liben, Paulus \& Rejeki, P. Sri. (2020). Terdapat Perbeaan Pengaruh Sirkuit Body Weight Training (CBWT) Submaksimal Terhadap Penurunan Persentase Lemak Tubuh, Lemak Subkutan dan Meningkatkan Otot Skeletal. Care:Jurnal Ilmiah Ilmu Kesehatan, 8(3), 472-482
\end{abstract}


penelitian adalah penelitian eksperimental dengan metode pretest-posttest design. Sampel 20 orang perempuan usia 18-23 tahun didapatkan menggunakan proportionate stratified random sampling, yang terdiri dari K1 10 orang terlatih dan K2 10 orang tidak terlatih. Dilakukan pengukuran persentase lemak tubuh, lemak subkutan dan otot skeletal menggunakan timbangan Body Composition Monitor model HBF-375 Karada Scan. Latihan CBWT submaksimal (64-76\% denyut jantung maksimal) selama 30 menit, dan 5 menit setelah CBWT dilakukan pengukuran kembali setelah perlakuan. Data dianalisis menggunakan SPSS dengan uji statistik paired t-test sesudah itu dilanjut independent t-test. lemak tubuh selisih antara pre dan post $\mathrm{K} 1$ dengan rerata $\Delta(0,53 \% \pm 0,28)$, dan $\mathrm{K} 2$ rerata $\Delta$ $(0,92 \% \pm 0,69)$, nilai $\mathrm{p}=0,119(\mathrm{p}<0,05)$. lemak subkutan selisih antara pre dan post $\mathrm{K} 1$ dengan rerata $\Delta(0,34 \% \pm 0,16)$, dan $\mathrm{K} 2$ rerata $\Delta(0,43 \% \pm 0,40)$, nilai $\mathrm{p}=0,528(\mathrm{p}<0,05)$. Otot skeletal selisih antara pre dan post K1 dengan rerata $\Delta(0,41 \% \pm 0,23)$, dan K2 rerata $\Delta$ $(0,33 \% \pm 0,29)$, nilai $\mathrm{p}=0,506(\mathrm{p}<0,05)$. CBWT submaksimal dapat menurunkan persentase lemak tubuh, lemak subkutan dan meningkatkan otot skeletal pada K1 dan K2 tetapi perbedaan tersebut tidak bermakna.

Kata Kunci : CBW'T; komposisi tubuh; orang terlatih; orang tidak terlatih.

\section{PENDAHULUAN}

Obesitas dapat didefinisikan sebagai kelebihan lemak tubuh. Obesitas terjadi akibat masukan energi yang melebihi pengeluaran energi (Guyton \& Hall, 2014). Lebih dari 1,9 miliar orang dewasa berusia 18 tahun ke atas mengalami kelebihan berat badan dan 600 juta orang dewasa yang obesitas, secara keseluruhan, sekitar 13\% dari populasi orang dewasa seluruh dunia (11\% laki-laki dan 15\% perempuan) yang mengalami obesitas pada tahun 2014. Sedangkan 39\% dari orang dewasa berusia 18 tahun ke atas (38\% laki-laki dan 40\% perempuan) mengalami kelebihan berat badan (WHO, 2016). Berdasarkan Hasil Riset Kesehatan Dasar Nasional (Riskesdasnas) Indonesia tahun 2018, prevalensi obesitas pada tahun $2013(14,8 \%)$ dan mengalami peningkatan pada tahun 2018 (21,8\%)

(Kementrian Kesehatan RI, 2018).

Obesitas merupakan permasalahan yang harus ditangani, karena obesitas dapat terjadi pada siapa saja, baik anak-anak, dewasa maupun orang tua. Ketika obesitas tidak ditangani maka dapat menimbulkan berbagai macam risiko utama penyakit seperti: penyakit kardiovaskular yang merupakan penyebab utama kematian pada tahun 2012, penyakit diabetes militus, gangguan musculoskeletal (terutama osteoartritis atau penyakit degeneratif khususnya sendi), beberapa penyakit kanker (endometrium, payudara, ovarium, prostat, hati, kandung empedu, ginjal, dan usus besar), hipertensi, resistensi insulin dan efek psikologis (WHO, 2016). 
Obesitas timbul sebagai akibat masukan energi yang melebihi pengeluaran energy. Penyebab obesitas sangat kompleks. Penurunan aktivitas fisik dan pengaturan makan yang tidak baik merupakan penyebab obesitas, meskipun ada faktor lain penyebab obesitas seperti gen, gaya hidup dan faktor lingkungan. Orang terlatih mempunyai kualitas metabolisme dan proporsi oksidasi lemak lebih tinggi dibandingkan dengan orang yang tidak terlatih. Aktivitas fisik dan latihan fisik yang teratur dapat meningkatkan massa otot dan mengurangi masa lemak tubuh. Peningkatan aktivitas fisik merupakan cara yang efektif untuk mengurangi simpanan lemak (Guyton \& Hall, 2014).

Strategi yang efektif sebagai tindakan pencegahan sangat dibutuhkan. Latihan fisik termasuk salah satu strategi yang dapat dilakukan untuk mengatasi obesitas. Latihan intensitas submaksimal dapat dilaksanakan dengan berbagai tipe latihan, salah satunya melakukan berbagai jenis gerakan yang secara bergantian dan berat badan tubuh sebagai bebanya atau disebut circuit body weight training (CBWT). Latihan ini sudah popular dan digunakan di berbagai tempat kebugaran namun masih belum dapat dijelaskan pengaruh latihan circuit body weight training (CBWT) terhadap peningkatan kadar free fatty acid
(FFA) atau asam lemak bebas pada proses lipolysis (Buch A., et.al. 2017).

Pada penelitian sebelumnya tentang pengaruh pemberian perlakuan aktivitas fisik aerobik sesaat terhadap kadar trigliserida plasma pada orang terlatih dan tidak terlatih. Penelitian menggunakan metode pre-posttest design dengan tujuan untuk mengetahui pengaruh pemberian perlakuan aktivitas fisik aerobik sesaat terhadap kadar trigliserida plasma (Yusni, 2003).

Pada saat latihan fisik, lipid dioksidasi dari simpianan trigliserida dijaringan adiposa dan intramuskular. Trigliserida selanjutnya dirubah ke dalam bentuk gliserol dan asam lemak bebas yang akan digunakan sebagai sumber energi pada saat latihan fisik. Proses pemecahan trigliserida menjadi gliserol dan asam lemak bebas disebut lipolisis. Meningkatknya lipoisis pada saat latihan fisik berdampak terhadap meningkatnya penggunaan simpanan lemak, peningkatan penggunaan lemak endogen sebagai sumber energi selama latihan fisik akan menguntungkan untuk menurunkan simpanan lemak di jaringan adiposa sehingga dapat memberikan mafaat penurunan berat badan. Orang terlatih mempunyai kualitas metabolisme energi 
lebih tinggi dan proporsi oksidasi lemak pada orang terlatih lebih tinggi dibandingkan dengan yang tidak terlatih (Yusni, 2003). Berdasarkan latar belakang tersebut peneliti ingin membuktikan pengaruh aktivitas fisik submaksimal dengan metode latihan circuit body weight training (CBWT) terhadap komposisi tubuh (lemak tubuh, lemak subkutan dan otot skeletal) pada orang terlatih dan tidak terlatih. Tujuan penelitian ini untuk menganalisis pengaruh latihan fisik CBWT terhadap komposisi tubuh pada orang terlatih dan tidak terlatih.

\section{METODE PENELITIAN}

Penelitian yang dilakukan merupakan penelitian eksperimental dengan metode dengan metode factorial pretest-posttest design. Subjek adalah Subjek penelitian adalah berjenis kelamin perempuan usia 18-23 tahun. Subjek berjumlah 20 orang yang terdiri dari 2 kelompok, 10 orang sebagai kelompok tidak terlatih dan 10 orang sebagai kelompok terlatih. Sebelum bersedia menjadi sampel, para peserta mengisi form kesanggupan menjadi subyek penelitan (information of consent). Pemeriksaan kesehatan dan fisik (tinggi badan, berat badan, denyut nadi, tekanan darah) sampel penelitian perlu dilakukan.
Teknik pengambilan sampel pada penelitian ini adalah consekutive sampling yaitu subjek yang datang dan memenuhi kriteria pemilihan dimasukan dalam penelitian sampai jumlah subjek yang diperlukan terpenuhi. Pembagian menjadi 2 kelompok dilakukan pemilihan secara acak atau random. Kelompok yang terlatih dari cabang olahraga bola tangan dalam keadaan sehat, aktif olahraga atau latihan fisik secara teratur (4-6 kali seminggu) dan sudah melakukan latihan rutin lebih dari 6 bulan. Pada kelompok orang tidak terlatih kriteria sampel yang digunakan adalah dalam kondisi sehat, orang yang tidak melakukan olahraga atau latihan fisik secara teratur. Kriteria eksklusi adalah menderita gangguan muskuluskeletal, memiliki riwayat penyakit kronis (asma, paru dan jantung) dan sakit saat mengikuti protokol latihan. Besar total sampel pada penelitian ini adalah 20 orang didapatkan menggunakan proportionate stratified random sampling, terdiri dari 10 orang kelompok terlatih dan 10 orang dari kelompok tidak terlatih. Pengukuran komposisi tubuh yaitu persentase lemak tubuh, lemak subcutan dilakukan menggunakan timbangan Body Composition Monitor model HBF-375 Karada Scan (Kyoto, Japan). Pemanasan dilakukan sebelum melakukan CBWT. CBWT submaksimal (64-76\% 
denyut nadi maksimal) (Polar H7 \& H10, Finland) selama 30 menit. 5 menit setelah CBWT submaksimal dilakukan pra pengukuran.

Prosedur penelitian dilakukan untuk mengetahui tahapan yang dilakukan selama penelitan, sehingga resiko kegagalan dalam penelitian dapat dihindari. Pelaksanaan perlakuan dan pengukuran komposisi tubuh dilakukan di Fakultas Ilmu Olahraga Universitas Negeri Surabaya. Waktu penelitian dilakukan selama 1 hari dengan dua kali pengambilan data (pengambilan data pretest dan posttest). Pengarahan kepada subjek penelitian untuk tidak melakukan latihan fisik 24 jam sebelum mengikuti penelitian. Subjek penelitian diintruksikan untuk berpuasa 8 jam sebelum mengikuti penelitian, tidak boleh makan tetapi boleh minum hanya air mineral. Pengukuran komposisi tubuh dilakukan sebelum dan sesudah melakukan aktivitas fisik submaksimal CBWT.

Pemanasan dilakukan terlebih dahulu sebelum memulai aktivitas fisik intensitas submaksimal CBWT. Pemasangan alat pendeteksi denyut jantung (Polar H7 \& H10, Finland) kepada subjek penelitian supaya intensitas latihan bisa dikontrol sesuai yang diharapkan. Aktivitas fisik yang dilakukan oleh kelompok orang terlatih dan kelompok orang tidak terlatih sama. Aktivitas fisik submaksimal CBWT terdiri dari 10 gerakan (squat, $x$-jump, stationary lunges, burpees, push-ups, mountain climber, commandos, snap jump, straight leg raises, sit-ups) semua gerakan dilakukan 12 repetisi dari gerakan satu ke gerakan selanjutnya tanpa istirahat. Target denyut jantung individu dalam pelaksanaan latihan harus mencapai kisaran 64-73\% dari denyut jantung maksimal dan aktivitas fisik dilakukan selama 30 menit. Pengukuran komposisi tubuh dilakukan 5 menit setelah aktivitas fisik dengan sistem recovery pasif.

Data hasil penelitian dianalisa secara statistik menggunakan bantuan program uji statistic SPSS versi 16.0. tahapan analisa data meliputi uji deskriptif digunakan untuk mengetahui sebaran data, Uji normalitas menggunakan Shapiro-Wilk untuk mengetahui distribusi data tersebut normal, kemudian dilanjutkan uji beda mengunakan paired $t$ test apabila data berdistribusi normal atau apabila data tidak berdistribusi normal digunakan uji Wilcoxon Sign Rank Test, untuk mengetahui perbedaan komposisi tubuh maka dilakukan uji independent $t$ test apabila data berdistribusi normal dan 
dilakukan uji Mann Whithney apabila data

tidak berdistribusi normal.

\section{HASIL}

Tabel 1. Rerata dan simpangan baku umur, berat badan, tinggi badan seluruh subjek

\section{Rerata \pm SD}

\begin{tabular}{lllll}
\hline Kelompok & Umur (th) & BB $(\mathrm{kg})$ & TB $(\mathrm{m})$ & IMT $\left(\mathrm{kg} / \mathrm{m}^{2}\right)$ \\
Terlatih & 20,50 & 60,83 & 1,666 & 21,93 \\
(K1) & $\pm 0,70$ & $\pm 2,60$ & $\pm 3,20$ & $\pm 1,23$ \\
Tidak Terlatih & 20,50 & 51,57 & 1,546 & 21,57 \\
(K2) & $\pm 0,70$ & $\pm 3,46$ & $\pm 2,06$ & $\pm 1,13$ \\
\hline
\end{tabular}

Data deskriptif variabel umur, berat badan, tinggi badan, Indeks Masa Tubuh (IMT) kelompok 1 (kelompok terlatih) dan kelompok 2 (kelompok tidak terlatih) dapat dilihat pada (tabel 1). Hasil rerata umur 20,5 th, berat badan $60,83 \mathrm{~kg}$, tinggi badan $1,666 \mathrm{~cm}$ dan IMT $21,93 \mathrm{~kg} / \mathrm{m}^{2}$ subjek penelitian pada kelompok terlatih (K1), sedangkan hasil rerata umur 20,5 th, berat badan 51,57 kg, tinggi badan 1,546 $\mathrm{cm}$ dan IMT $21,57 \mathrm{~kg} / \mathrm{m}^{2}$ subjek penelitian pada kelompok tidak terlatih (K2).

Tabel 2. Uji normalitas kelompok tidak terlatih

\begin{tabular}{llll}
\hline Variabel & & \multicolumn{2}{c}{ Uji Normalitas } \\
& $\mathrm{n}$ & Statistik & Sig. \\
LT $(\%)$ pre & 10 & 0,967 & $0,858^{*}$ \\
LT $(\%)$ post & 10 & 0,959 & $0,778^{*}$ \\
LS $(\%)$ pre & 10 & 0,954 & $0,712^{*}$ \\
LS $(\%)$ post & 10 & 0,951 & $0,677^{*}$ \\
OS $(\%)$ pre & 10 & 0,949 & $0,657^{*}$ \\
OS $(\%)$ post & 10 & 0,949 & $0,660^{*}$ \\
\hline
\end{tabular}

*Catatan $\mathrm{p}>0,05$ menunjukan data variabel berdistribusi normal

Hasil uji normalitas dengan menggunakan uji Shapiro-Wilk didapatkan bahwa data lemak tubuh pre dan post, lemak subkutan pre dan post, otot skeletal pre dan post, pada kelompok tidak terlatih (Tabel 2) dan kelompok terlatih (Tabel 3) memiliki distribusi normal yaitu dengan $\mathrm{p}$ $>0,05$.

Tabel 3. Uji normalitas kelompok terlatih

\begin{tabular}{|c|c|c|c|}
\hline \multirow[t]{2}{*}{ Variabel } & \multicolumn{3}{|c|}{ Uji Normalitas } \\
\hline & $\mathrm{n}$ & Statistik & Sig. \\
\hline LT $(\%)$ pre & 10 & 0,982 & $0,973^{*}$ \\
\hline $\mathrm{LT}(\%)$ post & 10 & 0,953 & $0,705^{*}$ \\
\hline $\mathrm{LS}(\%)$ pre & 10 & 0,946 & $0,616^{*}$ \\
\hline $\mathrm{LS}(\%)$ post & 10 & 0,969 & $0,880^{*}$ \\
\hline OS $(\%)$ pre & 10 & 0,882 & $0,138^{*}$ \\
\hline OS (\%) post & 10 & 0,887 & $0,121 *$ \\
\hline \multicolumn{4}{|c|}{$\begin{array}{l}{ }^{*} \text { Catatan } \mathrm{p}>0,05 \text { menunjuk } \\
\text { variabel berdistribusi normal } \\
\text { Keterangan Tabel } 2 \text { dan Tabel } 3\end{array}$} \\
\hline
\end{tabular}


Hasil paired t-test terhadap variabel lemak tubuh pre dan post, lemak subkutan pre dan post, otot skeletal pre dan post, kelompok tidak terlatih dan kelompok terlatih dapat dilihat (gambar 1). Berdasarkan hasil uji statistik data hasil penelitian didapatkan bahwa Lemak tubuh pre perlakuan $\mathrm{K} 1(24,21 \% \pm 1,77)$ dan pra perlakuan $\mathrm{K} 1(23,68 \% \pm 1,85)$, nilai $p=0,000(p<0,05)$. Lemak tubuh pre perlakuan K2 $(29,08 \% \pm 2,74)$ dan pra perlakuan $\mathrm{K} 2(28,16 \% \pm 2,79)$, nilai $\mathrm{p}=$ $0,002(\mathrm{p}<0,05)$. Lemak subkutan pre perlakuan K1 $(22,28 \% \pm 1,69)$ dan pra perlakuan $\mathrm{K} 1(22,28 \% \pm 1,69)$, nilai $\mathrm{p}=$ $0,000 \quad(\mathrm{p}<0,05)$. Lemak subkutan pre perlakuan K2 $(24,51 \% \pm 1,93)$ dan pra perlakuan $\mathrm{K} 2(23,96 \% \pm 1,90)$, nilai $\mathrm{p}=$ $0,000 \quad(\mathrm{p}<0,05)$. Otot skeletal pre perlakuan K1 $(29,65 \% \pm 1,19)$ dan pra perlakuan $\mathrm{K} 1(30,06 \% \pm 1,19)$, nilai $\mathrm{p}=$ $0,000 \quad(\mathrm{p}<0,05)$. Otot skeletal pre perlakuan K2 $(25,92 \% \pm 1,01)$ dan pra perlakuan K2 $(26,28 \% \pm 1,04)$, nilai $\mathrm{p}=$ $0,003(\mathrm{p}<0,05)$.

Hasil independent t-test terhadap variabel lemak tubuh selisih antara pre dan post Tabel 4. Independent t-test
K1 dengan rerata $\Delta(0,53 \% \pm 0,28)$, dan $\mathrm{K} 2$ rerata $\Delta(0,92 \% \pm 0,69)$, nilai $\mathrm{p}=0,119$ $(\mathrm{p}<0,05)$. lemak subkutan selisih antara pre dan post $\mathrm{K} 1$ dengan rerata $\Delta$ $(0,34 \% \pm 0,16)$, dan $\mathrm{K} 2$ rerata $\Delta(0,43 \% \pm$ $0,40)$, nilai $\mathrm{p}=0,528(\mathrm{p}<0,05)$. Otot skeletal selisih antara pre dan post K1 dengan rerata $\Delta(0,41 \% \pm 0,23)$, dan $\mathrm{K} 2$ rerata $\Delta(0,33 \% \pm 0,29)$, nilai $\mathrm{p}=0,506$ $(\mathrm{p}<0,05)$ (tabel 4).

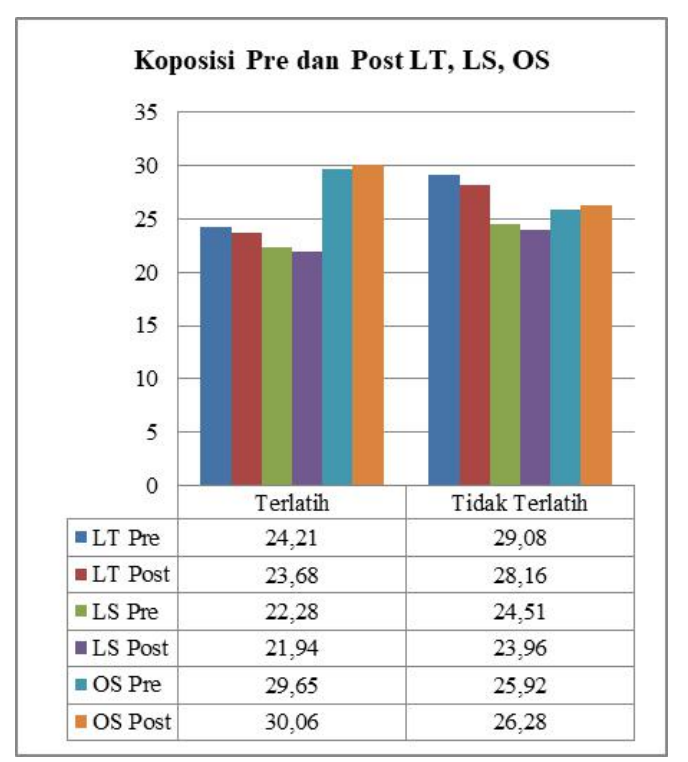

Gambar 1. Komposisi Pre dan Post lemak tubuh, lemak subkutan dan otot skeletal pada kelompok terlatih dan tidak terlatih.

Keterangan Gambar 1
LT
: Lemak Tubuh
LS
: Lemak Subkutan
OS
: Otot Skeletal

Rerata \pm SD

\begin{tabular}{lllll}
\hline Kelompok & Umur (th) & BB $(\mathrm{kg})$ & TB $(\mathrm{m})$ & IMT $\left(\mathrm{kg} / \mathrm{m}^{2}\right)$ \\
Terlatih & 20,50 & 60,83 & 1,666 & 21,93 \\
(K1) & $\pm 0,70$ & $\pm 2,60$ & $\pm 3,20$ & $\pm 1,23$ \\
Tidak Terlatih & 20,50 & 51,57 & 1,546 & 21,57 \\
(K2) & $\pm 0,70$ & $\pm 3,46$ & $\pm 2,06$ & $\pm 1,13$ \\
\hline
\end{tabular}




\section{PEMBAHASAN}

Berdasarkan analisis data hasil penelitian menunjukan bahwa terdapat pengaruh yang signifikan CBWT submaksimal terhadap penurunan persentase lemak tubuh, lemak subkutan dan peningkatan otot skeletal pada orang terlatih dan tidak terlatih. Terjadi penurunan presentase lemak tubuh antara Pre dan Post test baik pada K1 maupun K2, tetapi tidak ada perbedaan yang signifikan, dengan nilai $\mathrm{p}=0,119 \quad(\mathrm{p}<0,05)$. Latihan fase akut tampak menyebabkan peningkatan sirkulasi kadar hormon yang paling banyak. Latihan fisik dengan intensitas submaksimal dapat meningkatkan 5-10 kali lipat oksidasi lemak dibandingkan pada saat istirahat, karena peningkatan energi otot dan asam lemak ditingkatkan ketersediaanya. Sebagian besar peningkatan jumlah asam lemak diakibatkan dari hasil lipolisis dari TG pada jaringan adiposa. Latihan intensitas submaksimal dapat meningkatkan 10 kali lipat lebih cepat aliran darah ke otot rangka (Jeffrey and Samuel, 2000).

Pada penelitian lain dengan jenis latihan daya tahan dan resistance training selama 10 minggu, 3 hari per minggu, menunjukan penurunan yang signifikan pada persentase lemak tubuh (Ucan Y, 2013).
Metode latihan terbaik yang disarankan adalah kombinasi latihan daya tahan dan resistance training, karena jenis latihan tersebut dianggap efektif meningkatkan fat free mass dan menurunkan fat mass (Hoffman, 2002).

Terjadi penurunan presentase lemak subkutan antara Pre dan Post test baik pada K1 maupun K2, tetapi tidak ada perbedaan yang signifikan dengan nilai $\mathrm{p}=0,528(\mathrm{p}<0,05)$. Aktivitas fisik CBW'T dengan intensitas submaksimal memberikan pengaruh penurunan lemak subkutan tetapi tidak ada perbedaan yang signifikan. Latihan akut menunjukan bahwa latihan intensitas tinggi mungkin lebih efektif dari pada latihan intensitas rendah sampai intensitas sedang untuk memobilisasi abdominal viceral fat dengan menginduksi sekresi hormon lipolitik dan memfasilitasi pengeluaran energi lebih besar pasca latihan dan meningkatkan oksidasi lemak. Pada latihan bigh intensity exercise training adalah jenis latihan yang efektif untuk menurunkan lemak subkutan (Irving et al, 2008).

Selama latihan dengan intensitas rendah energi yang digunakan sebanyak 90\% dari asam lemak bebas 100 unit energi. Selama 
latihan dengan intensitas tinggi energi yang digunakan adalah 75\% dari asam lemak bebas 200 unit energi. 90\% dari 100 unit energi adalah 90, sedangkan 75\% dari 200 unit energi adalah 150. Namun tidak hanya intensitas, tetapi durasi latihan dan keadaan individu juga dipertimbangkan. Terdapat korelasi antara durasi (lamanya) latihan dengan penggunaan lemak sebagai sumber energi (Horowitz \& Klein, 2000). Latihan dengan intensitas moderate (40-65\% $\mathrm{VO}_{2 \max }$ ) lemak pada jaringan adiposa dan intramuskular digunakan sebagai sumber energi, dapat meningkatkan hormon katekolamin dan mengakibatkan terjadinya metabolisme lemak (McMurray \& Hackney, 2005).

Terjadi peningkatan persentase otot skeletal antara Pre dan Post test baik pada K1 maupun K2, tetapi tidak ada perbedaan yang signifikan dengan nilai $\mathrm{p}$ $=0,506(\mathrm{p}<0,05)$. Intesitas dan beban latihan submaksimal berada di bawah atau mendekati ambang batas anaerobik dapat meningkatkan kadar asam laktat darah dengan cepat. Pada orang terlatih, ambang batas anaerobik ini tercapai pada beban $70-85 \%$ denyut jantung maksimal, sedangkan pada orang yang tidak terlatih, ambang batas anaerobik terjadi pada beban yang lebih rendah (Yusni, 2003).
Menurut Klien, 2003 terdapat korelasi antara durasi latihan dengan penggunaan lemak sebagai sumber energi. Selama latihan fisik intensitas sedang terjadi peningkatan lipolisis dua sampai tiga kali lipat pada jaringan adiposa yang ada diseluruh tubuh waktu latihan 30 menit dan semakin meningkat dengan durasi latiahan yang semakin lama, mencapai sekitar lima kali lipat lebih tinggi dibandingkan dengan istirahat 4 jam (Thomas \& Matthew, 2015).

Hal ini memberikan gambaran setelah melakukan CBWT submaksimal pada kedua kelompok mengalami penurunan persentase lemak tubuh dan lemak subkutan, peningkatan persentase otot skeletal. Berdasarkan hasil uji statistik penurunan persentase lemak tubuh, lemak subkutan dan peningkatan persentase otot skeletal pada kelompok tidak terlatih lebih banyak dibandingkan pada kelompok terlatih. Pengaruh CBWT submaksimal selama 30 menit sudah memberikan respon terhadap penurunan komposisi lemak tubuh, lemak subkutan dan peningkatan otot skeletal. Berdasarkan hasil uji statistik perbedaan tersebut tidak bermakna. 


\section{KESIMPULAN}

Terdapat pengaruh CBWT submaksimal terhadap penurunan persentase lemak tubuh dan lemak subkutan dan peningkatan persentase otot skeletal pada K1 dan pada K2. Penurunan persentase lemak tubuh, lemak subkutan dan peningkatan persentase otot skeletal pada K1 lebih banyak dibandingkan pada K2. Tidak ada perbedaan yang signifikan antara penurunan persentase lemak tubuh dan lemak subkutan dan peningkatan persentase otot skeletal K1 dan K2.

\section{SARAN}

Subjek penelitian lebih dikontrol mengenai aktivitas fisik sebelum penelitian, diet, dan hal-hal lainya yang mempengaruhi variabel penelitian. Dosis dan metode latihan perlu diperhatikan, perlu dilakukan penelitian yang serupa dengan menggunakan sampel yang lebih banyak.

\section{REFERENSI}

Buch A., Kis O., Carmeli E., KeinanBoker L., Berner Y., Barer Y., Ster N, 2017. Circuit Resistance Training is an effective means to Enhance Muscle Strength in Older Adults. Ageing Research Reviews. 37, 16-27. Elsevier. http://dx.doi.org/doi:10.1016/j.arr. 2017.04.003

Guyton AC \& Hall JE, 2014. Metabolisme dan Pengaturan Suhu, in Arthur C. Guyton \& John E.
Hall. Buku Ajar Fisiologi

Kedokteran.12 ${ }^{\text {th }}$ ed,. Singapore: Saunders Elsivier, Penangung jawab terjemah Ermita I. Ibrahim ilyas.

Hendry, Widhi, Billy, 2016. Perbedaan Profil Lipid pada Remaja Obes dan Tidak Obes di Kecamatan Bolangitang Barat. Journal e-Biomedi (eBm), Volume 4, Nomor 2. Fakultas Kedokteran Universitas Sam Ratunlangi Manado.

Hoffman J, 2002. Physiological Aspects of Sport Training and Performance. Human Kinetics Publications. 128129.

Horowitz JF, and Klein S, 2000. Lipid Metabolism During Endurance Exercise $^{1-3}$.The American Journal of Clinical Nutrition. 2000;72 (2):558S-63S. American Society for Clinical Nutrition. doi: 10.1093/ajcn/72.2.558S

Irving B.A, Davis C.K, Brock D.W, Weltman Y, Swift D, Barrett E.J, Gaesser G, Weltman A. 2009. Effect of Exercise Training Intensity on Abdominal Viceral Fat and Body Composition. Med Sci Sports Exerc. 2008 November ;40(11): 1863-1872. doi:10.1249/MSS.0b013e3181801d 40.

Kementrian Keseharan RI. 2018. Hasil Utama Riskesdas 2018. Kementrian Kesehatan RI, Badan Penelitian dan Pengembangan Kesehatan. Jakarta.

McMurray R,G and Hackney A, C. 2005. Interactions of Metabolic Hormones, Adipose Tissue and Ex888ercise. University of Nort Carolina at Chapel Hill, North Carolina, USA. Journal Sport Med. 35 (5): 393-412 DOI: $\quad 10.2165 / 00007256-$ 200535050-00003

Suharjana, 2007. Latihan Beban. Yogyakarta: Fakultas Ilmu Keolahragaan Universitas Negeri Yogyakarta. 
Thomas T, Matthew JW, 2015. Exercise and the Regulation of Adipose Tissue Metabolism. Progress in Molecular Biology and Translation Science. Depatement of Physiology, Monash University, Clayton, Victoria, Australia. doi: 10.1016/bs.pmbts.2015.06.016.

Ucan Y, 2013. Effects of Different Types of Exercise on Body Composition in Young Men and Women. Life Science Journal.2013;10(3):17991806.(ISSN:1097-8135). http://www.lifesciencesite.com. 269

Yusni, 2003. Pengaruh Aktivitas Fisik Aerobik Sesaat Terhadap Kadar Trigliserida Plasma Pada Orang Tidak Terlatih dan Terlatih Suatu Pendekatan Lipolisis (Tesis). Fakultas Kedokteran. Universitas Airlangga Surabaya.

Widodo, F.Y., 2007. Lipolisis. Surabaya. Departement of Biochemistry. University of Wijaya Kusuma Surabaya Medical Faculty.

World Health Organization. Media Centre. Obesity and Overweight. 2016. Available at: http://who.int/mediacentre/factsh eets/fs311/en/ 